\title{
IMPLEMENTASI PEMBELAJARAN “INQUIRY SMALL RESEARCH” \\ UNTUK MENINGKATKAN SIKAP ILMIAH DAN PRESTASI BELAJAR MAHASISWA PENDIDIKAN BIOLOGI
}

\author{
Wachidatul Linda Yuhanna ${ }^{1 *}$, Raras Setyo Retno ${ }^{2}$, Juwanita $^{3}$ \\ ${ }^{1}$ Prodi Pendidikan Biologi, FKIP, Universitas PGRI Madiun, Jl. Setia Budi No. 85 Madiun \\ ${ }^{2}$ Prodi PGSD, FKIP, Universitas PGRI Madiun, Jl. Setia Budi No. 85 Madiun \\ ${ }^{3}$ Prodi Pendidikan Biologi, FKIP, Universitas PGRI Madiun, Jl. Setia Budi No. 85 Madiun \\ ${ }^{*}$ E-mail: \\ linda.yuhanna.wiguno@gmail.com \\ Telp: 082234469131
}

\begin{abstract}
This research aims to implement Inquiry Small Research to improve the scientific attitude and achievement of students in vertebrate zoology This research was conducted in second semester with 38 students. This classroom action research is conducted in 2 cycles, each cycle through planning, action, observation and reflection. Data collection using observation sheet to know the scientific attitude and cognitive test to measure student achievement. The results showed that implementation of Inquiry Small Research for scientific attitude of students with good and excellent category experienced an increase from pre-cycle and cycle I by $54 \%$, and from cycle I and II increased by $6 \%$. Thus, overall from the pre-cycle stage to cycle II, students' scientific attitudes increased by $60 \%$. The increase of student achievement by $27 \%$, from pre cycle and cycle I, from cycle I and cycle II experienced $39 \%$ improvement. Thus, overall from pre-cycle stage to cycle II, student achievement has increased by $66 \%$. The conclusion of this research is through implementation of Inquiry Small Research can improve scientific attitude and student achievement.
\end{abstract}

Keywords : inquiry small research; scientific attitude; student achievement

\section{PENDAHULUAN}

Pembelajaran sains merupakan bagian penting dari pendidikan. Proses Sains berkaitan dengan cara yang digunakan untuk memperoleh pengetahuan dengan sikap tertentu yang dikenal dengan sikap ilmiah (scientific attitude) yang merujuk pada perubahan tingkah laku yang teliti, jujur, obyektif, non-bias, berpikir rasional, dan kritis (Sani, 2014; Astawa et.al, 2015; Natalina et.al, 2013). Sikap ilmiah tersebut sangat penting dalam kehidupan karena dapat membentuk pribadi manusia yang selalu menggunakan logika dalam pertimbangan suatu keputusan.

Biologi merupakan cabang ilmu pengetahuan bagian dari sains atau IPA yang mempelajari proses dan gejala alam, sifat alam serta penerapannya. Belajar biologi tidak hanya sekedar fakta-fakta yang harus dihafalkan, akan tetapi memerlukan pemahaman tentang proses secara sistematis dan aplikasinya dalam kehidupan nyata (Seniwati, 2015). Zoologi vertebrata merupakan salah satu mata kuliah biologi dalam bidang keilmuan dan keterampilan (MKK) yang wajib ditempuh oleh mahasiswa Program Studi Pendidikan Biologi.

Permasalahan yang terjadi pada pembelajaran zoologi vertebrata adalah kurangnya pengembangan sikap ilmiah mahasiswa selama perkuliahan. Mahasiswa kurang antusias dalam pelaksanaan praktikum, tidak disiplin, tidak tepat waktu, kurangnya kemampuan menganalisis data hasil praktikum, pemalsuan data praktikum dan kurangnya kemampuan mengkomunikasikan hasil praktikum kepada mahasiswa lain. Proses pembelajaran melalui praktikum selama ini hanya berpusat pada dosen, laboran dan buku saja, mahasiswa kurang berperan aktif dalam menemukan sendiri konsep belajarnya. Hal tersebut kurang mengasah kemampuan berpikir mahasiswa sehingga pengetahuan yang didapat mahasiswa hanya berupa teori yang dihapal dan mudah dilupakan, yang akan berdampak pada rendahnya prestasi belajar mahasiswa.

Pelaksanaan pembelajaran mata kuliah zoologi vertebrata sebaiknya mengedepankan pada keseimbangan 3 unsur penting dari IPA yaitu konten, proses atau metode dan sikap ilmiah. Pembelajaran yang tidak seimbang antara proses dan produk menyebabkan mahasiswa tidak dapat menumbuhkan dan mengembangkan sikap ilmiah yang terdapat dalam dirinya. Hal tersebut mengakibatkan pengetahuan yang didapat oleh mahasiswa hanya berupa teori yang dihapal, 
sehingga pengetahuan tersebut menjadi tidak bermakna dan mudah dilupakan, yang akan berdampak pada rendahnya prestasi belajar mahasiswa. Faktanya, mahasiswa yang telah mengikuti kegiatan praktikum di laboratorium masih ada yang mendapatkan nilai $C$. Proses pembelajaran yang tidak seimbang antara proses dan produk tersebut, juga berpengaruh terhadap penanaman scientific characters pada mahasiswa.

Inquiry small research merupakan serangkaian kegiatan (proyek kecil) yang melibatkan seluruh kemampuan mahasiswa dalam memecahkan suatu permasalahan melalui langkahlangkah sistematis dan menuntut mahasiswa mengkonstruksi sendiri konsep pembelajarannya. Metode ini merupakan pengembangan dari metode inkuiri yang mengedepankan kemampuan mandiri dalam menemukan konsep (Hendarwati, 2016; Hapsari et.al, 2012; Umami et.al, 2013). Proses pembelajaran Inquiry Small Research tersebut membuat mahasiswa berpikir untuk menemukan sendiri konsep belajarnya melalui langkah-langkah yang sistematis seperti merumuskan masalah, mengajukan hipotesis, melakukan penelitian, mencatat hasil penelitian, mengolah data, menganalisis dan menyimpulkan yang dilandasi dengan sikap ilmiah seperti jujur, terbuka, toleran, tekun, optimis, berani, bekerjasama, skeptic, tidak tergesa-gesa dan memiliki keingintahuan yang tinggi. Adanya pengembangan proyek mandiri tersebut, mahasiswa akan tertantang dan menumbuhkan sikap ilmiah serta dapat meningkatkan prestasi belajarnya (Sukaesih, 2011; Suansah, 2015).

Kurniawati et.al (2016) menyatakan bahwa prestasi belajar merupakan hasil belajar setelah mengikuti program pembelajaran yang dinyatakan dengan skor atau nilai. Prestasi dapat diartikan sebagai hasil capaian atau hasil nyata yang diperoleh seseorang setelah melakukan suatu kegiatan (Suatmaji, 2010). Prestasi adalah hasil dari suatu kegiatan yang dapat diciptakan, dilakukan dan menyenangkan hati, diperoleh dengan jalan keuletan kerja, baik secara individu maupun kelompok.

Hendracipta (2016) dan Maroangi et.al (2015) menyatakan bahwa dalam mengembangkan sikap sikap ilmiah melalui kegiatan pembelajaran berbasis inkuiri harus mengandung unsur kegiatan untuk memupuk sikap ilmiah yang meliputi obyektif atau jujur, tidak tergesa-gesa, terbuka, tidak mencampuradukkan fakta dengan pendapat, bersikap hati-hati, sikap ingin menyelidiki atau keingintahuan (couriosity) yang tinggi. Nikmah (2015) dan Pradianti et.al (2015) menyatakan bahwa sikap ilmiah yang dapat dikembangkan meliputi, sikap ingin tahu, sikap kritis, sikap terbuka, sikap objektif, sikap rela menghargai karya orang lain, sikap berani mempertahankan kebenaran, dan sikap menjangkau ke depan.

Tujuan dari penelitian ini adalah mengimplementasikan pembelajaran Inquiry Small Research untuk meningkatkan sikap ilmiah dan prestasi belajar mahasiswa program studi Pendidikan Biologi pada mata kuliah zoologi vertebrata.

\section{METODOLOGI PENELITIAN}

Penelitian ini dilakukan pada mahasiswa Pendidikan Biologi semester II sejumlah 38 mahasiswa, mulai dari bulan Maret sampai Agustus 2017. Instrumen yang digunakan yaitu lembar observasi sikap ilmiah dan tes kognitif untuk mengukur prestasi belajar mahasiswa, yang dilaksanakan di akhir pembelajaran. Indikator ketercapaian dalam penelitian ini meliputi indikator ketercapaian sikap ilmiah dan ketuntasan prestasi belajar secara klasikal mencapai $75 \%$.

Penelitian ini merupakan Penelitian Tindakan Kelas (classroom action research) dengan 2 siklus. Masing-masing siklus dilaksanakan dengan tahapan perencanaan, pelaksanaan, pengamatan dan refleksi (Arikunto, 2014). Teknik analisis data menggunakan deskriptif kuantitatif dengan menghitung prosentase sikap ilmiah dan ketuntasan belajar mahasiswa. Data sikap ilmiah dihitung dengan persamaan berikut ini.

Sikap Ilmiah $=\frac{\Sigma \text { skor yang diperoleh }}{\Sigma \text { skor maksimum }} \times 100 \%$

Kriteria sikap ilmiah :

0-40 : Kurang Baik

$41-60$ : Cukup Baik

$61-80$ : Baik

81-100: Sangat Baik

Prosentase sikap ilmiah secara klasikal:

Sikap Ilmiah $=\frac{\Sigma \text { Mahasiswa skor } B+S B}{\Sigma \text { mahasiswa }} \times 100 \%$

Data prestasi belajar dihitung dengan persamaan sebagi berikut:

Prestasi $=\frac{\Sigma \text { skor yang diperoleh }}{\Sigma \text { skor maksimum }} \times 100 \%$

Kriteria prestasi belajar :

0-74 : Tidak Tuntas

75-100: Tuntas

Prosentase prestasi belajar secara klasikal: 
Prestasi $=\frac{\Sigma \text { mahasiswa tuntas }}{\Sigma \text { mahasiswa }} \times 100 \%$

\section{HASIL DAN PEMBAHASAN}

Berdasarkan pengamatan awal saat proses pembelajaran mata kuliah zoologi vertebrata pada mahasiswa semester II, $40 \%$ mahasiswa terlihat dapat menerapkan sikap ilmiahnya dan $60 \%$ mahasiswa cukup dapat menerapkan sikap ilmiahnya walaupun belum sempurna. Prestasi belajar mahasiswa belum tuntas secara klasikal.

\section{Siklus I}

Proses pembelajaran pada mata kuliah zoologi vertebrata dengan menerapkan pembelajaran Inquiry Small Research, mahasiswa dianjurkan melaksanakan praktikum secara mandiri dan berkelompok untuk merancang sebuah proyek penelitian.

\section{Perencanaan}

Kegiatan yang dilakukan peneliti pada tahap ini meliputi 1) Peneliti melakukan musyawarah tentang penelitian yang akan dilakukan, 2) Membuat rencana pembelajaran semester (RPS), menyusun lembar evaluasi dan materi pembelajaran, menyusun instrumen penilaian, menyiapkan alat dan bahan praktikum.

\section{Pelaksanaan}

Kegiatan yang dilakukan adalah melaksanakan skenario pembelajaran Inquiry Small Research menggunakan perangkat pembelajaran yang telah disiapkan. Peneliti melaksanakan proses pembelajaran sesuai dengan rencana pelaksanaan pembelajaran yaitu dosen membuka perkuliahan dengan salam kemudian mengecek kehadiran mahasiswa serta memberi apersepsi dan menyampaikan tujuan pembelajaran, mahasiswa membuat rancangan penelitian yang disetujui dosen, melaksanakan penelitian, membuat laporan sementara, mempresentasikan hasil laporan, membuat laporan secara mandiri dan melaksanakan post test.

\section{Pengamatan}

Pengamatan sikap ilmiah mahasiswa dilakukan oleh peneliti dibantu oleh 4 orang observer menggunakan lembar observasi. Data prestasi belajar diambil melalui pos tes setelah praktikum.

Tabel 1. Pengamatan sikap ilmiah siklus II

\begin{tabular}{lcc}
\hline \multicolumn{1}{c}{ Kriteria } & $\begin{array}{c}\text { Frekuensi } \\
\text { (mahasiswa) }\end{array}$ & $\begin{array}{c}\text { Prosentase } \\
(\mathbf{\%})\end{array}$ \\
\hline 81-100 (Sangat Baik) & 36 & 94 \\
61-80 (Baik) & - & - \\
41-60 (Cukup Baik) & - & - \\
0-40 (Kurang Baik) & 2 & 6 \\
\hline Jumlah & 38 & 100 \\
\hline
\end{tabular}

Berdasarkan tabel 1. dapat diketahui bahwa dari keseluruhan mahasiswa 94\% mempunyai sikap ilmiah dengan kategori sangat baik. Hasil tersebut telah memenuhi indikator pencapaian sikap ilmiah mahasiswa yaitu apabila pencapaian sikap ilmiah mahasiswa secara klasikal mencapai $\geq 75 \%$. Namun, masih perlu dilakukan pengamatan kembali pada siklus berikutnya karena terdapat 2 mahasiwa yang belum memenuhi indikator ketercapaian sikap ilmiah.

Tabel 2. Prestasi belajar siklus I

\begin{tabular}{lcc}
\hline \multicolumn{1}{c}{ Kriteria } & $\begin{array}{c}\text { Frekuensi } \\
\text { (mahasiswa) }\end{array}$ & $\begin{array}{c}\text { Prosentase } \\
(\boldsymbol{\%})\end{array}$ \\
\hline 0-74 (Tidak tuntas) & 18 & 47 \\
75-100 (Tuntas) & 20 & 53 \\
\hline Jumlah & 38 & 100 \\
\hline
\end{tabular}

Berdasarkan tabel 2. dapat diketahui bahwa dari jumlah total 38 mahasiswa, terdapat 20 mahasiswa yang mencapai ketuntasan belajar atau hanya 53\%, sedangkan 18 siswa lainnya belum mencapai ketuntasan belajar atau $47 \%$ mahasiswa yang belum tuntas. Sehingga tingkat ketuntasan secara klasikal mencapai 53\%. Hasil tersebut belum mencapai ketuntasan belajar secara klasikal yaitu sebesar $\geq 75 \%$, sehingga perlu adanya perbaikan pada siklus berikutnya.

\section{Refleksi}

Berdasarkan hasil pengamatan dan analisis data tentang sikap ilmiah dan prestasi belajar mahasiswa, maka dapat diketahui kekurangankekurangan proses pembelajaran pada siklus I. 
Adapun beberapa kendala atau kekurangan tersebut dapat direfleksikan sebagai berikut:

a. Prestasi belajar mahasiswa melalui implementasi Inquiry Small Research belum mencapai ketuntasan belajar seperti yang telah ditentukan. Hal tersebut disebabkan masih kurangnya pemahaman mahasiswa terhadap materi dan metode pembelajaran yang dilaksanakan.

b. Peralatan praktikum kurang memadai, banyak kelompok yang kekurangan papan parafin dan jarum suntik, sehingga harus bergantian dengan kelompok lain. Selain itu, mahasiswa juga belum dapat memanajemen waktu dengan baik.

Upaya yang dilakukan untuk meningkatkan sikap ilmiah dan prestasi belajar mahasiswa yaitu:

a. Mahasiswa ditekankan untuk belajar lebih mendalam mengenai materi yang akan dipraktikumkan dan memberikan kisi-kisi materi dan soal yang akan diberikan pada pertemuan selanjutnya.

b. Mahasiswa mengajukan daftar peralatan praktikum yang dibutuhkan kepada asisten dosen sebelum praktikum dilaksanakan, sehingga asisten dosen dapat menyiapkan peralatan lebih lengkap.

c. Mahasiswa diharapkan dapat menggunakan waktu dengan baik, sehingga pembelajaran dapat berlangsung dengan tepat waktu dan tertib.

Hasil analisis dan refleksi ini digunakan dalam proses pembelajaran pada siklus II. Sehingga sikap ilmiah dan prestasi belajar mahasiswa diharapkan mengalami peningkatan.

\section{Siklus II}

Berdasarkan permasalahan yang ditemukan pada pelaksanaan siklus I, perlu dilakukan perbaikan-perbaikan pembelajaran pada siklus II. Hal tersebut diharapkan pada pembelajaran siklus II dapat meningkatkan sikap ilmiah dan prestasi belajar mahasiswa melalui pencapaian indikatorindikator yang telah ditetapkan. Adapun langkahlangkah yang akan dilakukan pada siklus II adalah:

\section{Perencanaan}

Tahap perencanaan pada siklus II, peneliti bersama dosen mempersiapkan instrumeninstrumen yang diperlukan diantaranya RPP, lembar observasi sikap ilmiah dan soal pos tes.

\section{Pelaksanaan}

Peneliti melaksanakan proses pembelajaran sesuai dengan rencana pelaksanaan pembelajaran yaitu dosen membuka pelajaran dengan salam kemudian mengecek kehadiran mahasiswa serta memberi apersepsi dan menyampaikan tujuan pembelajaran, mahasiswa membuat rancangan penelitian yang disetujui dosen, melaksanakan penelitian, membuat laporan sementara, mempresentasikan hasil laporan, membuat laporan secara mandiri dan melaksanakan pos tes.

\section{Pelaksanaan}

Hasil pengamatan sikap ilmiah dan prestasi belajar mahasiswa disajikan dalam tabel 3 dan 4 .

Tabel 3. Pengamatan sikap ilmiah siklus II

\begin{tabular}{lcc}
\hline \multicolumn{1}{c}{ Kriteria } & $\begin{array}{c}\text { Frekuensi } \\
\text { (mahasiswa) }\end{array}$ & $\begin{array}{c}\text { Prosentase } \\
(\%)\end{array}$ \\
\hline 81-100 (Sangat Baik) & 37 & 97 \\
61-80 (Baik) & 1 & 3 \\
41-60 (Cukup Baik) & - & - \\
0-40 (Kurang Baik) & - & - \\
\hline Jumlah & 38 & 100 \\
\hline
\end{tabular}

Tabel 2. Prestasi belajar siklus II

\begin{tabular}{lcc}
\hline \multicolumn{1}{c}{ Kriteria } & $\begin{array}{c}\text { Frekuensi } \\
\text { (mahasiswa) }\end{array}$ & $\begin{array}{c}\text { Prosentase } \\
(\mathbf{\%})\end{array}$ \\
\hline 0-74 (Tidak tuntas) & 3 & 8 \\
75-100 (Tuntas) & 35 & 92 \\
\hline Jumlah & 38 & 100 \\
\hline
\end{tabular}

Berdasarkan tabel 3. dapat diketahui bahwa sikap ilmiah mahasiswa dengan kategori baik dan sangat baik. Sikap ilmiah mahasiswa pada siklus I semula $94 \%$ meningkat menjadi $100 \%$ pada siklus II. Sehingga terjadi peningkatan sebanyak $6 \%$. Hal tersebut dikarenakan mahasiswa sangat tertarik dan antuasis terhadap praktikum yang dilakukan.
Prestasi belajar mahasiswa telah mencapai indikator keberhasilan yang diharapkan, yaitu sebanyak 35 mahasiswa (92\%) telah mencapai ketuntasan belajar dan 3 mahasiswa (8\%) belum mencapai ketuntasan belajar. Hasil tersebut menunjukkan bahwa ketuntasan belajar secara klasikal sudah tercapai, $\geq 75 \%$ mahasiswa mencapai ketuntasan belajar. 


\section{Refleksi}

Berdasarkan hasil observasi yang dilakukan pada siklus II dapat diketahui adanya peningkatan sikap ilmiah dan prestasi belajar mahasiswa yang teridentifikasi melalui lembar observasi dan nilai hasil tes belajar mahasiswa pada mata kuliah Zoologi Vertebrata.

Melalui pembelajaran Inquiry Small Research pada mata kuliah zoologi vetebrata telah mencapai hasil yang telah ditentukan. Indikator ketercapaian sikap ilmiah secara klasikal adalah $75 \%$ dan prestasi belajar secara klasikal $75 \%$ sudah dapat dicapai dengan baik, sehingga perlakuan dan penelitian tindakan kelas ini dinyatakan berhasil. Berdasarkan hasil tersebut, maka siklus dalam pembelajaran ini dihentikan sampai siklus II, kemudian dianalisis temuan di lapangan yang terjadi selama pembelajaran berlangsung.

\section{Peningkatan Sikap Ilmiah Mahasiswa}

Implementasi pembelajaran berbasis inquiry small research melalui praktikum, dimana dalam praktikum tersebut memuat tahap-tahap kerja ilmiah. Mahasiswa dilatih untuk memahami dan mengerjakan praktikum sesuai dengan tahapantahapan tersebut. Menurut Carin (dalam Sukaesih, 2011) menyatakan bahwa terdapat serangkaian sikap dan nilai yang dapat ditumbuhkan melalui kerja ilmiah yaitu 1) memupuk rasa ingin tahu (being curious) tentang dunia sekitarnya. 2) mengutamakan bukti dalam arti kesimpulan yang diperoleh perlu ditunjang oleh bukti empiris. 3) menjadi skeptis yaitu siswa yang terlibat kerja ilmiah harus skeptis terhadap konklusi atau pendapat orang lain. 4) mau menerima perbedaan dan menghormati pandangan yang berbeda. 5) Bekerjasama (kooperatif) dan bersikap positif.

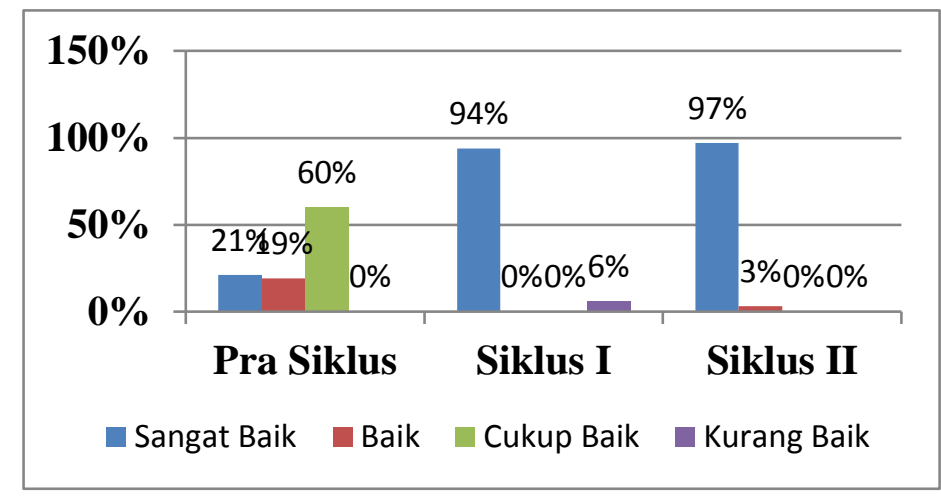

Gambar 1. Peningkatan sikap ilmiah mahasiswa

Menurut Astawa et.al (2015), Pradianti et.al (2015) menyatakan bahwa pengembangan sikap ilmiah mampu memberikan karakter bagi peserta didik sesuai dengan nilai-nilai ilmiah. Mahasiswa yang memiliki rasa keinginan tahuan yang tinggi, kritis terhadap suatu permasalahan, jujur, selalu mendahulukan bukti, kreatif, dan terbuka merupakan ciri mahasiswa yang selalu berpikir dan bertindak secara ilmiah, terstruktur, dan mandiri. Sehingga pengembangan sikap ilmiah dikalangan mahasiswa sangat diperlukan untuk membangun kemandirian mahasiswa dalam memecahkan suatu masalah.

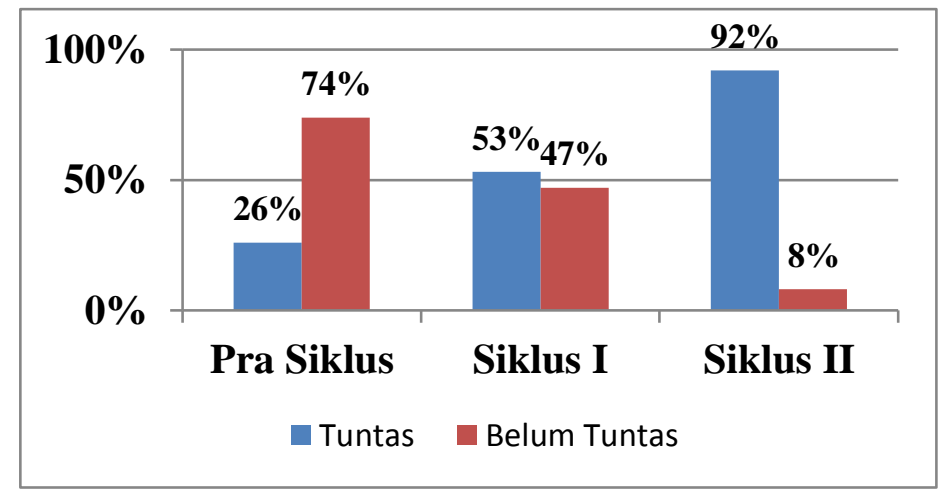

Gambar 2. Peningkatan prestasi belajar mahasiswa

Berdasarkan tabel 4. dan gambar 2. dapat diketahui bahwa terjadi peningkatan prestasi belajar mahasiswa sebesar $27 \%$, dari tahap pra siklus dan siklus I, dan terjadi peningkatan belajar mahasiswa dari siklus I dan siklus II sebesar 39\%. Sehingga, secara keseluruhan dari tahap pra siklus, siklus I dan 
II, prestasi belajar mahasiswa melalui implementasi pembelajaran Inquiry Small Research mengalami peningakatan sebesar $66 \%$.

Histogram tersebut juga menunjukkan adanya peningkatan jumlah ketuntasan belajar mahasiswa pada setiap siklusnya. Hasil peneliti tersebut didukung dengan penelitian yang dilakukan oleh Kurniawati, et.al (2016), Siregar (2013) menunjukkan bahwa melalui penerapan model pembelajaran inkuiri terbimbing dapat meningkatkan prestasi belajar siswa. Hal tersebut didukung dengan teori yang dikemukakan oleh Gulo (dalam Mashuri, 2012) menjelaskan bahwa, inquiry tidak hanya mengembangkan kemampuan intelektual tetapi seluruh potensi yang ada termasuk pengembangan emosional dan pengembangan keterampilan. Berdasarkan hakekatnya pembelajaran inkuiri merupakan sebuah proses. Proses ini bermula dari merumuskan masalah, mengembangkan hipotesis, mengumpulkan bukti,

\section{KESIMPULAN}

Kesimpulan dari penelitian ini adalah melalui implementasi Inquiry Small Research dapat meningkatkan sikap ilmiah dan prestasi belajar mahasiswa.

\section{UCAPAN TERIMAKASIH}

Ucapan terimakasih disampaikan kepada Kemenristekdikti atas pembiayaan melalui hibah penelitian dosen pemula, mahasiswa pendidikan biologi dan observer penelitian.

\section{DAFTAR PUSTAKA}

[1] Arikunto, S. 2014. Prosedur Penelitian Suatu Pendekatan Praktik. Jakarta: Rineka Cipta.

[2] Astawa, W. I. M., Sadia, W., \& Suastra, W. 2015. Pengaruh Model Pembelajaran Berbasis Proyek Terhadap Sikap Ilmiah dan Konsep Diri Siswa SMP. Jurnal Program Pascasarjana Universitas Pendidikan Ganesha, Vol. 5 (1) 1-11.

[3] Bahriah, E. S., Sofyatiningrum, E.,Irwandi, D.2014.Peningkatan Penguasaan Konsep Kesetimbangan Kimia dengan Pendekatan Inkuiri Terintegrasi Nilai. Edusains, Vol. 4 (2) 177-184.

[4] Hapsari, D. P., Sudarisman, S., \& Marjono. 2012. Pengaruh Model Inkuiri Terbimbing dengan Diagram V (Vee) dalam Pembelajaran Biologi Terhadap Kemampuan Berpikir Kritis dan Hasil menguji hipotesis dan menarik kesimpulan sementara, menguji kesimpulan sementara menjadi kesimpulan akhir yang dapat diyakini oleh peserta didik. Melalui proses pembelajaran secara langsung tersebut, materi atau informasi yang didapat mahasiswa akan lebih mudah diserap dan diingat oleh mahasiswa (Retno dan Yuhanna, 2016). Pembelajaran berbasis proyek mandiri juga memberi ruang kepada mahasiswa untuk mengoptimalkan kemampuan diri dan bereksplorasi secara leluasa sehingga mahasiswa lebih kreatif dan berpikir kritis

Pradianti et.al, (2015) dan Bahriah et.al (2014) menyatakan bahwa pembelajaran Inquiry dianggap dapat menanamkan pemahaman dan pengertian serta membimbing mahasiswa agar mampu memahami konsep dan prinsip sains. Pembelajaran Inquiry juga mampu mengembangkan kemampuan berpikir dan memecahkan masalah sesuai dengan konsep yang telah dipahaminya.

Belajar Siswa. Jurnal Pendidikan Biologi, Vol. 4(3) 16-28.

[5] Hendarwati, E. 2013. Pengaruh Pemanfaatan Lingkungan Sebagai Sumber Belajar Melalui Metode Inkuiri Terhadap Hasil Belajar Siswa SDN I Sribit Delanggu Pada Pelajaran IPS. Pedagogia, Vol. 2 (1), 59-70. [6] Hendracipta, N. 2016. Menumbuhkan Sikap Ilmiah Siswa Sekolah Dasar Melalui Pembelajaran IPA Berbasis Inkuiri. JPSD, Vol. 2 (1), 109-116.

[7] Kurniawati, D., Masykuri, M., \& Saputro, S. 2016. Penerapan Model Pembelajaran Inkuiri Terbimbing Dilengkapi LKS untuk Meningkatkan Keterampilan Proses Sains Dan Prestasi Belajar pada Materi Pokok Hukum Dasar Kimia Siswa Kelas X MIA 4 SMA N 1 Karanganyar Tahun Pelajaran 2014/2015. Jurnal Pendidikan Kimia (JPK), Vo. 5(1), 88-95.

[8] Maroangi, Y., Werdhiana, K., \& Tiwow, M, A. 2015. Pengaruh Model Pembelajaran Inquiri Melalui Keterampilan Proses Terhadap Hasil Belajar IPA di Kelas IV SDN Model Terpadu Madani Palu. Jurnal Mitra Sains, Vol. 3(1), 37-44.

[9] Mashuri, I. 2012. Pengaruh Pembelajaran Berbasis Masalah dan Inkuiri Ditinjau dari Kemandirian Belajar Siswa Kelas X SMA Negeri Kabupaten Blora. JMEE, Vol. 2(1), 19-35.

[10] Natalina, M., Mahadi, I., \& Suzane, A, C. 2013. Penerapan Model Pembelajaran Inkuiri Terbimbing (Guided Inquiry) untuk 
Meningkatkan Sikap Ilmiah dan Hasil Belajar Biologi Siswa Kelas XI IPA SMA Negeri 5 Pekanbaru Tahun Ajaran 2011/2012. Prosiding Seminar FMIPA Universitas Lampung, Lampung: UNILA.

[11] Nikmah, D. N. 2015. Implementasi Budaya Akademik dan Sikap Ilmiah Mahasiswa. Manajemen Pendidikan, Vol. 24 (6), 483490.

[12] Pradianti, D., Wasis., \& Agustini, R. 2015. Pengembangan Perangkat Pembelajaran Fisika Model Inkuiri Terbimbing untuk Melatihkan Kinerja Ilmiah Siswa. Jurnal Pendidikan Sains Pascasarjana Universitas Negeri Surabaya, Vol. 4(2), 672-680.

[13] Retno, R.S, Yuhanna, W.L. 2016. Pembelajaran Konsep Dasar IPA dengan Scientific Inquiry untuk Meningkatkan Kemampuan Berpikir, Bekerja dan Bersikap Ilmiah pada Mahasiswa. JPBI, Vol. 2(1) 19.

[14] Sani, R. A. 2014. Pembelajaran Saintifik untuk Implementasi Kurikulum 2013. Jakarta: PT Bumi Aksara.

[15] Seniwati. 2015. Peningkatan Aktivitas, Sikap dan Hasil Belajar Biologi Melalui
Penerapan Model Pembelajaran Inkuiri. Jurnal Nalar Pendidikan, Vol. 3 (1), 317321.

[16] Siregar, S. 2013. Pengaruh Model Pembelajaran Inkuiri Berbasis Media Animasi Terhadap Pemahaman Konsep, Sikap Ilmiah dan Assesmen Kinerja Siswa pada Konsep Sintesis Protein. Jurnal EduBio Tropika, Vol. 1, Edisi Khusus, 101106.

[17] Suansah. 2015. Penerapan Pendekatan Inkuiri Untuk Meningkatkan Keterampilan Proses Siswa Pada Pembelajaran IPA Pokok Bahasan Konduktor dan Isolator Panas. Profesi Pendidikan Dasar, Vol. 2 (1), 59-67.

[18] Sukaesih, S. 2011. Analisis Sikap Ilmiah Dan Tanggapan Mahasiswa Terhadap Penerapan Model Pembelajaran Berbasis Praktikum. Jurnal Penelitian Pendidikan, Vol. 28(1), 77-85.

[19] Umami, R., Pasaribu, M. \& Rede, A. 2013. Penerapan Metode Inkuiri Untuk Meningkatkan Hasil Belajar IPA Siswa Kelas IV SD Inpres Bajawali Kecamatan Lariang Kabupaten Mamuju Utara. Jurnal Kreatif Tadulako. Vol. 3 (2), 157-166. 